\title{
Detection of SARS-CoV-2 RNA with a Simple Concentration Method in Wastewater in Turkey: A Pilot Study in Çorum
}

\section{Türkiye'de Atık Suda SARS-CoV-2 RNA'nın Basit bir Konsantrasyon Yöntemiyle Tespit Edilmesi: Çorum'da Pilot Çalıșma}

Sabiha AYDOG̃DU' (IID), Djursun KARASARTOVA² (iiD), Ünsal SAVCI ${ }^{2}$ (iD), Ayșe Semra GÜRESER ${ }^{2}$ (IID), Gönül ARSLAN AKVERAN (ID), Merve AKTI (iD), Büșra GÜREL ${ }^{2}$ (IID), Çag̃daș KOCAMAN² (IID), Aytaç

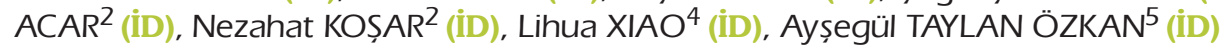

\footnotetext{
${ }^{1}$ Department of Nutrition and Dietetics, Hitit University Faculty of Health Sciences, Çorum, Turkey

${ }^{2}$ Department of Medical Microbiology, Hitit University Faculty of Medicine, Çorum, Turkey

${ }^{3}$ Food Processing Department, Hitit University Alaca Avni Çelik Vocational School, Çorum, Turkey

${ }^{4}$ South China Agricultural University, Collage of Veterinary Medicine, Guangzhou, China

${ }^{5}$ Department of Medical Microbiology, TOBB Economics and Technology University Faculty of Medicine, Ankara, Turkey
}

Cite this article as: Aydoğdu S, Karasartova D, Savcı Ü, Güreser AS, Arslan Akveran G, Aktı M, et al. Detection of SARS-CoV-2 RNA with a simple concentration method in wastewater in Turkey: A pilot study in Çorum. FLORA 2021;26(4):620-7.

\begin{abstract}
Introduction: Many studies have shown the advantages of monitoring wastewater in the evaluation of microbiological pathogens circulating in the community. It was aimed to detect of SARS-CoV-2 RNA with a simple concentration method in wastewater in this study.

Materials and Methods: In our study, 7 wastewater samples were investigated, which were collected from the Urban Wastewater Treatment Plant (WWTP) of Çorum, between October to November 2020. Sorbent bags were left in water for 24 hours. Then they were used to trap and concentrate the virus. Severe Acute Respiratory Syndrome Coronavirus 2 (SARS-CoV-2) RNA detected by using reverse transcription-quantitative polymerase chain reaction (RT-qPCR) assays.

Results: As a result, 3 of the 7 samples taken were positive for $N$ and ORF1ab target gene regions.

Conclusion: This is the first study reporting the detection of SARS-CoV-2 RNA in wastewater with different concentration and capture method.
\end{abstract}

Key Words: COVID-19; SARS-CoV-2; Wastewater 
ÖZ

\title{
Türkiye'de Atık Suda SARS-CoV-2 RNA'nın Basit bir Konsantrasyon Yöntemiyle Tespit Edilmesi: Çorum'da Pilot Çalıșma
}

\author{
Sabiha AYDOG̃DU', Djursun KARASARTOVA², Ünsal SAVCI², Ayșe Semra GÜRESER², \\ Gönül ARSLAN AKVERAN ${ }^{3}$, Merve AKTI², Büșra GÜREL 2 , Çã̃daș KOCAMAN², Aytaç ACAR², \\ Nezahat KOȘAR², Lihua XIAO ${ }^{4}$, Ayșegül TAYLAN ÖZKAN
}

\footnotetext{
${ }^{1}$ Hitit Üniversitesi Sag̃lık Bilimleri Fakültesi, Beslenme ve Diyetetik Bölümü, Çorum, Türkiye

${ }^{2}$ Hitit Üniversitesi Tıp Fakültesi, Tıbbi Mikrobiyoloji Anabilim Dalı, Çorum, Türkiye

${ }^{3}$ Hitit Üniversitesi Alaca Avni Çelik Meslek Yüksekokulu, Gıda ișleme Bölümü, Çorum, Türkiye

${ }^{4}$ Güney Çin Tarım Üniversitesi, Veteriner Hekimlik Bölümü, Guangzhou, Çin

5 TOBB Ekonomi ve Teknoloji Üniversitesi Tıp Fakültesi, Tıbbi Mikrobiyoloji Anabilim Dalı, Ankara, Türkiye
}

Giriş: Toplumda dolaşan mikrobiyolojik patojenlerin izlenmesinde atık suyu izlemenin avantajları birçok çalışmayla gösterilmiştir. Bizde çalışmamızda basit bir konsantrasyon metoduyla atık suda SARS-CoV-2 RNA tespit etmeyi amaçladık.

Materyal ve Metod: Çalışmamızda Ekim-Kasım 2020 tarihleri arasında Çorum Kentsel Atık Su Arıtma Tesisi'nden toplanan 7 atık su numunesi incelendi. Sorbent torbalar 24 saat suda bırakıldı. Torbalar virüsü yakalamak ve konsantre etmek için kullanıldı. SARS CoV-2 $R N A$, ters transkripsiyon-kantitatif polimeraz zincir reaksiyonu (RT-qPCR) testleri kullanılarak saptandı.

Bulgular: Sonuç olarak, alınan 7 numuneden 3'ü N ve ORF1ab hedef gen bölgeleri için pozitifti.

Sonuç: Çalışmamız, farkı konsantrasyon ve yakalama yöntemi ile atık sularda SARS-CoV-2 RNA tespitini bildiren ilk çalışmadır.

Anahtar Kelimeler: COVID-19; SARS-CoV-2; Atık su

\section{INTRODUCTION}

The novel coronavirus (SARS-CoV-2), which was first detected in December 2019 in Wuhan, China, caused a Public Health Emergency of International Concern about the new coronavirus disease (COVID-19) and global pandemic was officially declared by the World Health Organization $(\mathrm{WHO})^{[1]}$. Since that time, SARS-CoV-2 has spread to almost all countries and regions of the world, with 116.874 .912 confirmed cases and 2.597.381 confirmed deaths, according to $\mathrm{WHO}^{[2]}$. Turkey is among the countries affected by the pandemic.

Severe acute respiratory syndrome-related coronaviruses in the subgenus Sarbecovirus of the family Coronaviridae are a large family of viruses with single-stranded RNA, enveloped, and protein protrusions on the surface ${ }^{[3]}$. Coronaviruses are responsible for mild to moderately severe respiratory diseases as well as severe diseases such as MERS (Middle East respiratory syndrome), SARS (Severe acute respiratory syndrome) and
COVID-19 (Novel coronavirus disease). However, SARS-CoV-2 is known to have a higher transmission rate and infectivity than those of SARS-CoV and MERS-CoV ${ }^{[4]}$.

The respiratory disease called COVID-19 typically causes fever, dry cough, dyspnea, or severe pneumonia ${ }^{[5]}$. It is known that the main transmission route of the disease is inhalation from person-to-person aerosol transmission and direct contact, or fomite-to-hand contamination. Both live SARS-CoV-2 and viral RNA are found in a various specimens especially respiratory secretions, mucus, sputum and saliva. Currently, the most common and standard method used for COVID-19 diagnosis is the detection of SARS-CoV-2 in upper and lower respiratory specimens, including nasopharyngeal swabs, oropharyngeal swabs, sputum, aspirates, and bronchoalveolar lavage by real-time reverse transcription polymerase chain reaction (RT-PCR). The number and proportion of people infected with COVID-19 are mainly determined based on individual testing. On the 
other hand, the virus can be detected in serum, urine and faeces ${ }^{[6,7]}$. Patients can excrete the virus even if they are asymptomatic or pre-symptomatic and the pharyngeal samples obtained are negative, the stool may remain positive for SARS-CoV-2 for weeks by $\mathrm{PCR}^{[8,9]}$.

Sewage or wastewater, which are important sampling points, have been used for detection of pathogens in the community for years and its offer a practical approach to identify pathogens excreted in the faeces ${ }^{[10]}$. Wastewater-based epidemiology (WBE) is not as specific as clinical surveillance, but it provides opportunities to estimate the prevalence of viruses ${ }^{[11-13]}$. After the outbreak of SARS-CoV-2, presence of viruses RNA in wastewater was searched by researchers, and the virus was detected in many studies $^{[14-30]}$. Table 1 summarizes these researches. All of these studies have shown that wastewater monitoring can help understand the circulation of SARS-CoV-2 in human population.

According to our research, there is only one study indicating the presence of SARS-CoV-2 in wastewater in Turkey. Kocamemmi et al. have conducted the study in İstanbul, and RdRp gene has been used for virus detection ${ }^{[28]}$. Our study is the first study using the modified sorbent bag method on detecting SARS-CoV-2 in wastewater.

\section{MATERIALS and METHODS}

Between October to December 2020, 7 samples were taken (Table 2) from the Wastewater Treatment Plant (WWTP) in Corum, Turkey (Figure 1,2). Samples were taken weekly and, the concentration were performed using bags with sorbent method to trap viruses recommended by the WHO Guidelines for environmental surveillance of poliovirus circulation with some modifications $^{[31]}$. A sorbent bag was fixed on the field using fishing line. Thus, the bag was left in the stream of water. After exposure for 24 hours, the sorbent-bag was placed in a sterile flask and transported to the laboratory in a cold box. The bag with sorbent was placed in a sterile Petri dish and washed out with sterile distilled water (about $5 \mathrm{ml}$ ) using a pipette and, eluate was collected and investigated. After RNA extraction with viral nucleic acid buffer (Bio-Eksen), RT-qP-
CR was performed using the SARS-CoV-2 Double Gene RT-qPCR kit (Bio-Speedy). Nucleocapsid (N) and ORF1ab gene region were used to detect the presence of SARS-CoV-2 by RT-qPCR assays from wastewater. As other studies, samples were considered positive for $\mathrm{Ct}$ below 40 [26,27,29]

\section{RESULTS}

We measured SARS-CoV-2 RNA by RT-qPCR using $\mathrm{N}$ and ORF1ab primer sets. Of all RTqPCR quantification cycle (Cq) values, 42.8\% (3) were below 40, and all of these samples had a $\mathrm{Cq}$ value less than 37 . As a result, 3 out of 7 twenty-four hours raw wastewater samples were considered positive (Table 2).

\section{DISCUSSION}

Sewage systems are places where viruses are exposed to various temperatures and chemicals after being excreted in the faeces. Since virus concentration is also diluted with other waters and there are some inhibitors in these systems, it is very important even if viruses are detected in low titers in wastewater ${ }^{[32]}$. Wastewater monitoring is known to have resulted in successful public health interventions in the past. The most successful example of this has been implemented within the polio virus eradication program, and the number of infected cases has decreased ${ }^{[33]}$.

The main focus of the studies carried out in sewage systems related to SARS-CoV-2 is the isolation and detection of RNA in wastewater. SARS-CoV-2 is known to have poor stability in wastewater and is more sensitive to disinfectants than non-enveloped viruses ${ }^{[34]}$. However, there are many variables that can affect the detection and quantification of SARS-CoV-2 RNA. These are sampling method, sampling frequency, sampling types, sample storage conditions, pretreatment, virus concentration methods, RNA extraction methods, PCR format, target gene region and PCR performance characteristics ${ }^{[35]}$.

This study investigated the presence of SARSCoV-2 RNA in untreated wastewater samples and also evaluated the effectiveness of an alternative concentration method. For the detection of SARSCoV-2 in wastewater Polyethylene glycol (PEG) precipitation, ultracentrifugation and ultrafiltration methods were most frequently used for virus but 
Table 1. Summary of SARS-CoV-2 studies in wastewater conducted in 2020

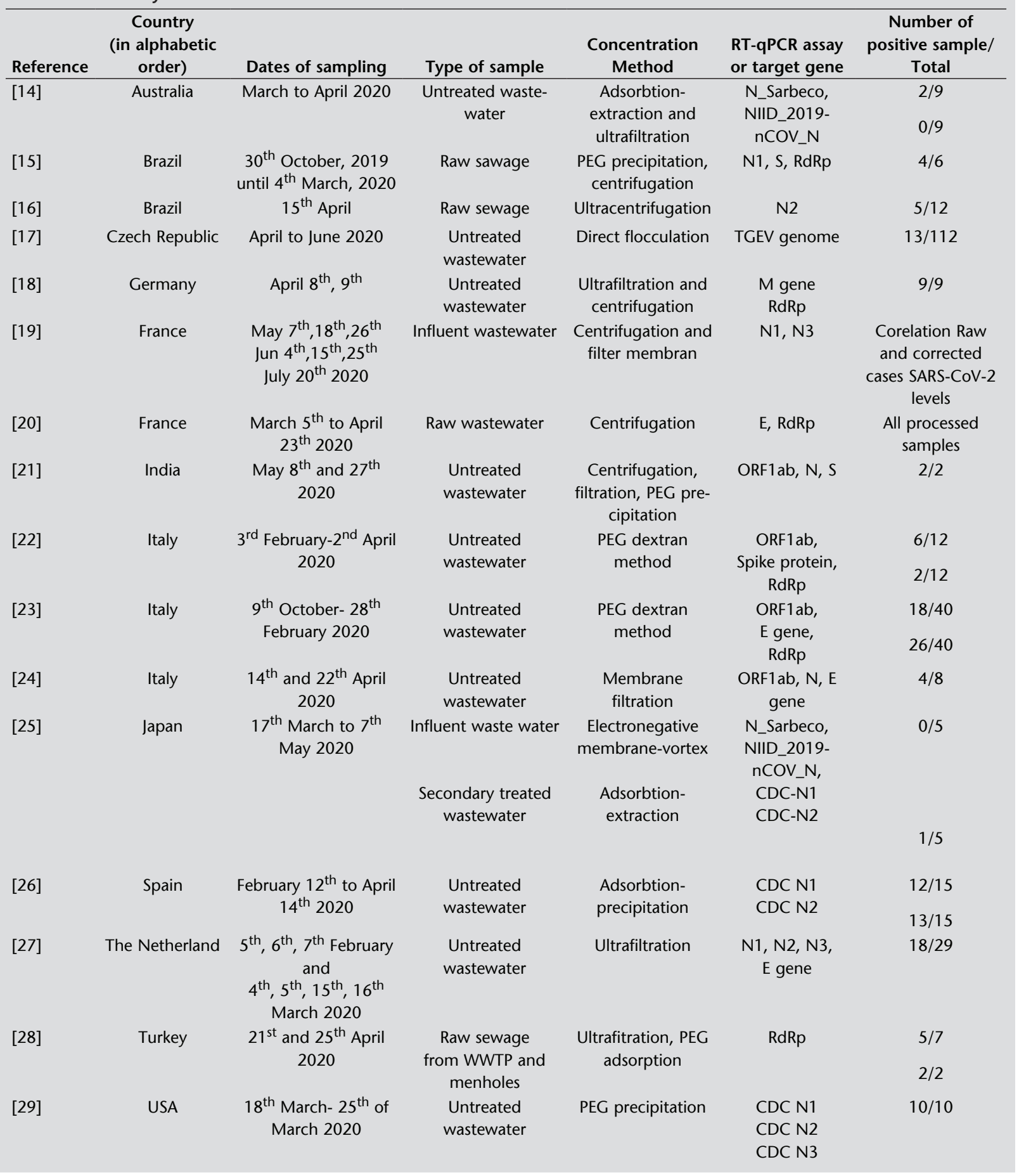


Table 1. Summary of SARS-CoV-2 studies in wastewater conducted in 2020 (continue)

\begin{tabular}{|c|c|c|c|c|c|c|}
\hline Reference & $\begin{array}{c}\text { Country } \\
\text { (in alphabetic } \\
\text { order) }\end{array}$ & Dates of sampling & Type of sample & $\begin{array}{c}\text { Concentration } \\
\text { Method }\end{array}$ & $\begin{array}{l}\text { RT-qPCR assay } \\
\text { or target gene }\end{array}$ & $\begin{array}{c}\text { Number of } \\
\text { positive sample/ } \\
\text { Total }\end{array}$ \\
\hline [30] & USA & $\begin{array}{l}\text { January } 13^{\text {th }} \text {, } \\
\text { February } 3^{\text {rd }}, \text { March } \\
2^{\text {nd }}, \text { April } 8^{\text {th }} \text { and } \\
29^{\text {th }} 2020\end{array}$ & $\begin{array}{l}\text { Untreated } \\
\text { wastewater }\end{array}$ & $\begin{array}{c}\text { Centrifugation and } \\
\text { ultrafiltration }\end{array}$ & $\begin{array}{l}\text { CDC N1 } \\
\text { CDC N2 }\end{array}$ & $2 / 15$ \\
\hline * & This study & $\begin{array}{l}\text { October } 22^{\text {th }} \text { and } \\
27^{\text {th }} ; 3^{\text {th }}, 11^{\text {th }}, 17^{\text {th }} \\
25^{\text {th }} \text { November; } 3^{\text {th }} \\
\text { December } 2020\end{array}$ & $\begin{array}{l}\text { Untreated } \\
\text { wastewater }\end{array}$ & $\begin{array}{l}\text { Modified sorbent } \\
\text { bags }\end{array}$ & $\mathrm{N}$ and ORF1 $\mathrm{ab}$ & $3 / 7$ \\
\hline
\end{tabular}

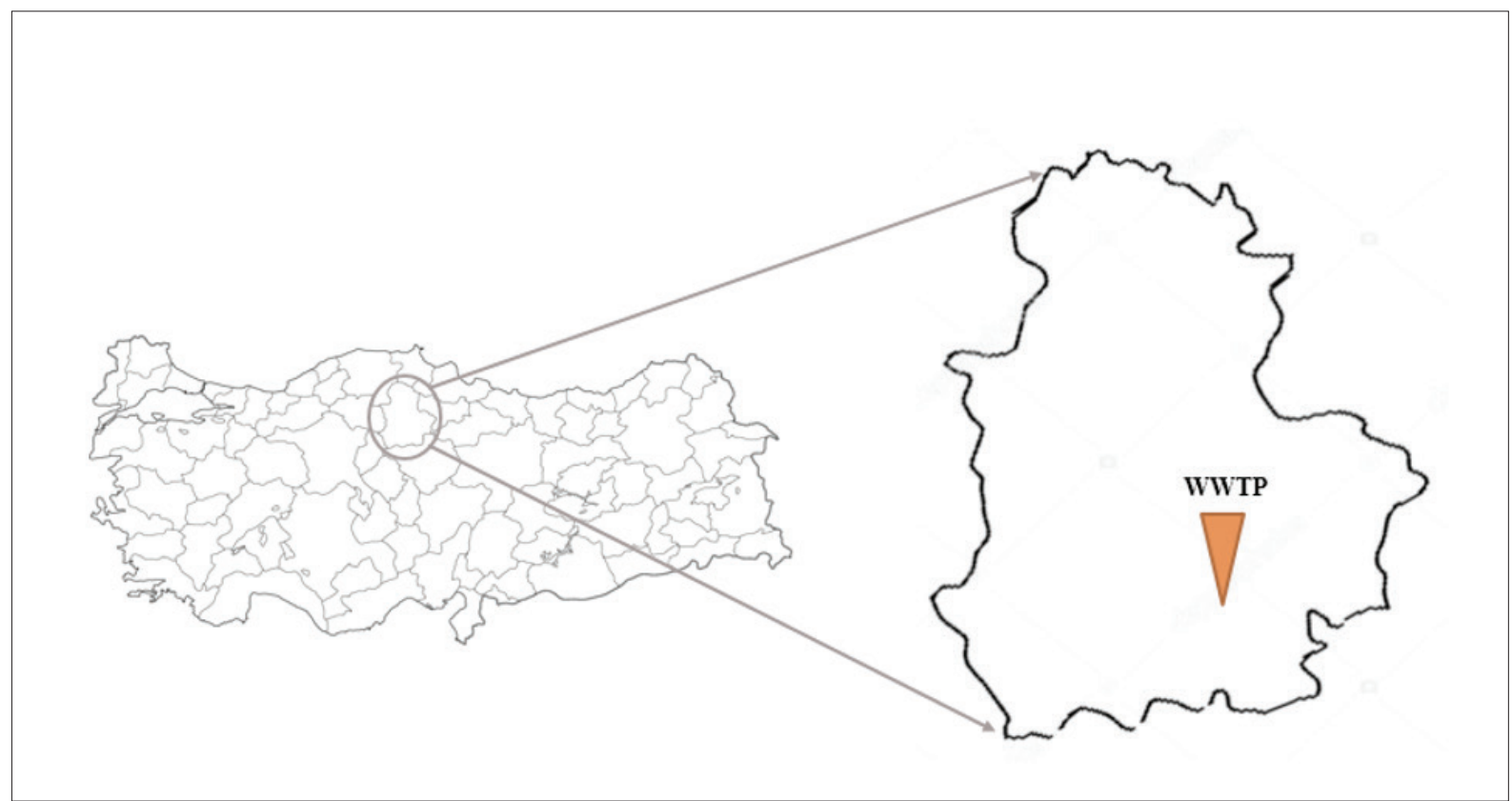

Figure 1. Çorum Province and WWTP on Turkey map.

WWTP: Wastewater treatment plant.

Table 2. Results of SARS-CoV-2 detection in the study period

\begin{tabular}{lccc}
\hline Week & Sampling date & Types of sample & RT-PCRassays (Cq value) \\
\hline 1 & $22 / 10 / 2020$ & 24 hours primary inlet wastewater & 36.93 \\
2 & $27 / 10 / 2020$ & 24 hours primary inlet wastewater & 36.77 \\
3 & $3 / 11 / 2020$ & 24 hours primary inlet wastewater & 36.36 \\
4 & $11 / 11 / 2020$ & 24 hours primary inlet wastewater & - \\
5 & $17 / 11 / 2020$ & 24 hours primary inlet wastewater & - \\
6 & $25 / 11 / 2020$ & 24 hours primary inlet wastewater & - \\
7 & $03 / 12 / 2020$ & 24 hours primary inlet wastewater & -
\end{tabular}




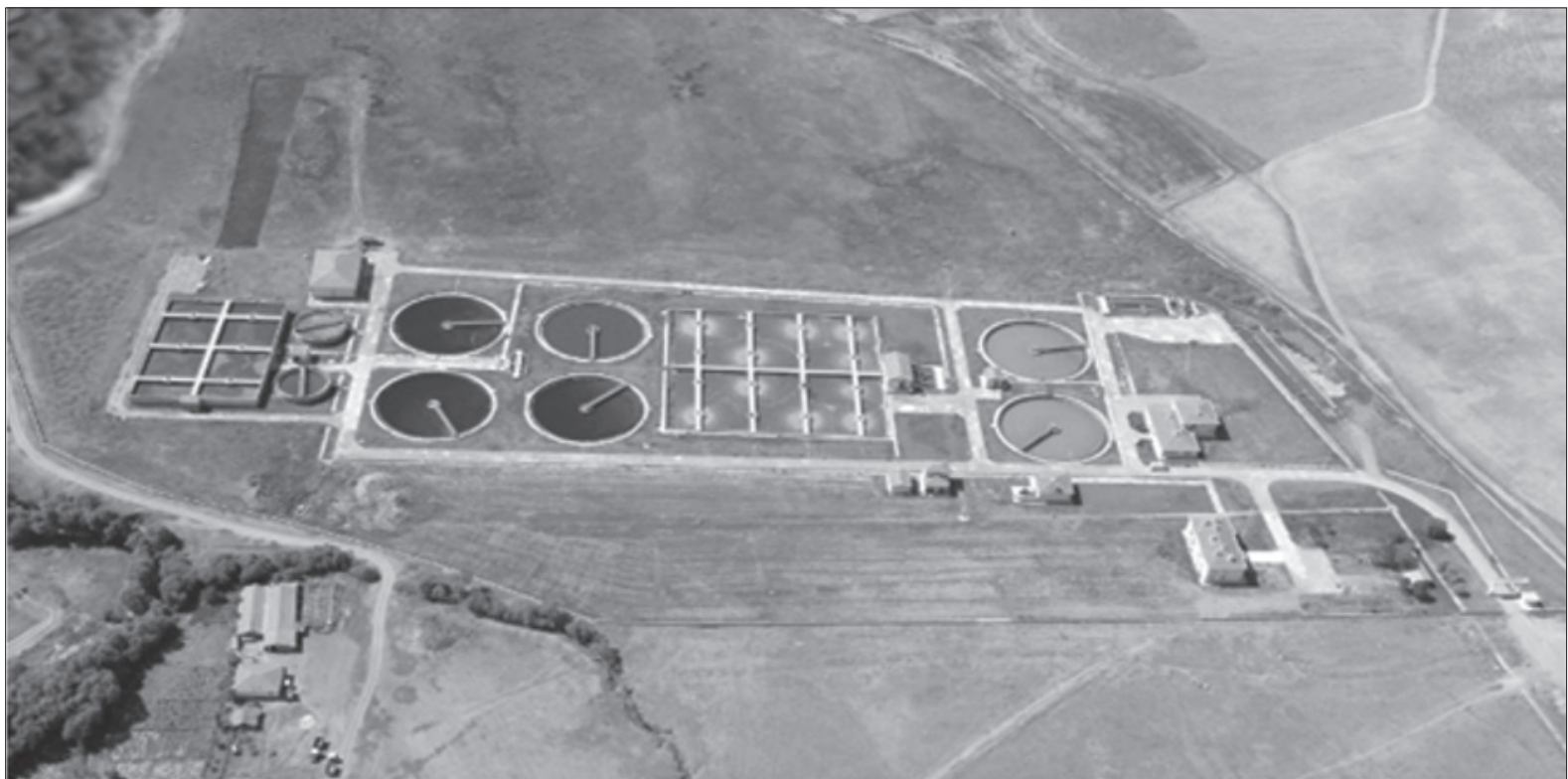

Figure 2. Wastewater treatment plant in Çorum.

studies show that there is lack of a standard method of concentration ${ }^{[36,37]}$. In this study, the sorbent bag method recommended in the WHO's World Health Organization's Guidelines on Environmental Surveillance of the Poliovirus Circulation Protocol was modified and a new concentration method was adapted to capture and concentrate viruses in wastewater ${ }^{[31]}$. Our study is the first and only study in the literature in which SARS-CoV-2 was detected using the modified sorbent bag method.

The first SARS-CoV-2 PCR tests were developed against the $\mathrm{E}$ and $\mathrm{N}$ gene, and these genes were used in numerous studies analyzing wastewater $^{[24-27,29,30]}$. Also, PCR targeting SARS-CoV-2 RdRP was used to a minor

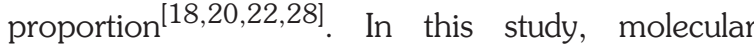
detection of SARS-CoV-2 RNA was carried out using the test kit based on detecting the $\mathrm{N}$ and Orf1b genes. The other study in Turkey on the detection of SARS-CoV-2 effluent samples were target of $\mathrm{RdRp} g e n e^{[28]}$. To our knowledge, our study is the first to detect SARS-CoV-2 RNA in environmental samples by targeting $\mathrm{N}$ and Orf1ab. In this study, $42.8 \%(3 / 7)$ of the wastewater samples showed positive results for SARS-CoV-2 RNA. Although the detection rates of the virus vary in studies, they all show that the virus can be detected in wastewater.

Monitoring the spread of SARS-CoV-2 disease in the community is very important to take appropriate precautions. But since most people are asymptomatic, the virus is very difficult to track. In financial terms, it is not possible to do clinical tests on all individuals. Under these conditions, with a passive but effective sewage or wastewater monitoring method, the circulation of SARS-CoV-2 in the population can be monitored, especially when clinical testing is limited. In this way, the number of infected individuals can be estimated. Most of these findings are the results of research studies. Only the Netherlands uses environmental surveillance as part of a routine COVID-19 monitoring package ${ }^{[38]}$. With a similar approach, sewage monitoring has been initiated in Germany, Australia and New Zealand ${ }^{[38]}$. The study is important in terms of showing the detectability of thevirus in wastewater in Turkey. Virus concentration method can serve as the basis for further research.

\section{Acknowledgements}

We thank Corum Municipality and all employees of the Wastewater Treatment Plant for their help in this study period. 


\section{ETHICS COMMITTEE APPROVAL}

For this study, it is not necessary to obtain the ethical approval because the study is conducted with the samples of wastewater (untreated sewage water).

\section{CONFLICT of INTEREST}

None of the authors had conflict of interest.

\section{AUTHORSHIP CONTRIBUTIONS}

Concept and Design: SA, DK, ATÖ

Data Collection or Processing: SA, U̇S, ASG, GAA, MA, BG, CK, AA, NK

Analysis/Interpretation: SA, DK, GAA, ATÖ

Literature Search: SA, ATÖ, LX

Writing: SA, ATÖ, LX

Final Approval: All of authors

\section{REFERENCES}

1. World Health Organization (WHO). Coronavirus disease (COVID-19) pandemic. Available from: https://www.euro. who.int/en/health-topics/health-emergencies/coronavirus-covid-19/novel-coronavirus-2019-ncov (Accessed date: 10 December 2020).

2. World Health Organization (WHO). Coronavirus disease (COVID-19) pandemic. Available from: https://www.who. int/emergencies/diseases/novel-coronavirus-2019 (Accessed date: 9 March 2021).

3. Coronaviridae Study Group of the International Committee on Taxonomy of Viruses. The species Severe acute respiratory syndrome-related coronavirus: classifying 2019-nCoV and naming it SARS-CoV-2. Nat Microbiol 2020;5:536-44.

4. Xu Z, Shi L, Wang Y, Zhang J, Huang L, Zhang C, et al. Pathological findings of COVID-19 associated with acute respiratory distress syndrome. Lancet Respir Med 2020;8:42022.

5. Lima CMAO. Information about the new coronavirus disease (COVID-19). Radiol Bras 2020;53:V-VI.

6. Kim JM, Kim HM, Lee EJ, Jo HJ, Yoon Y, Lee NJ, et al. Detection and Isolation of SARS-CoV-2 in Serum, Urine, and Stool Specimens of COVID-19 Patients from the Republic of Korea. Osong Public Health Res Perspect 2020;11:112-17.

7. Peng L, Liu J, Xu W, Luo Q, Chen D, Lei Z, et al. SARS-CoV-2 can be detected in urine, blood, anal swabs, and oropharyngeal swabs specimens. J Med Virol 2020;92:1676-80.

8. Chen C, Gao G, Xu Y, Pu L, Wang Q, Wang L, et al. SARS-CoV-2-positive sputum and feces after conversion of pharyngeal samples in patients with COVID-19. Ann Intern Med 2020:172:832-34

9. Xiao F, Tang M, Zheng X, LiU Y, Li X, Shan H. Evidence for gastrointestinal infection of SARS-CoV-2. Gastroenterology 2020:158;1831-3.e3.
10. La Rosa G., Muscillo M. Molecular detection of viruses in water and sewage. In: Cook N., (ed). Viruses in Food and Water: Risks, Surveillance and Control. Woodhead Publishing Limited; Cambridge, UK: 2013:97-125.

11. Kitajima $M$, Ahmed W, Bibby K, Carducci A, Gerba CP, Hamilton $K A$, et al. SARS-CoV-2 in wastewater: State of the knowledge and research needs. Sci Total Environ 2020;739:139076.

12. Farkas K, Marshall M, Cooper D, MCDonald JE, Malham SK, Peters $D E$, et al. Seasonal and diurnal surveillance of treated and untreated wastewater for human enteric viruses. Environ Sci Pollut Res Int 2018;25:33391-401.

13. Markosian C, Mirzoyan N. Wastewater-based epidemiology as a novel assessment approach for population-level metal exposure. Sci Total Environ 2019;689:1125-32.

14. Ahmed W, Angel N, Edson I, Bibby K, Bivins A, O'Brien JW, et al. First confirmed detection of SARS-CoV-2 in untreated wastewater in Australia: A proof of concept for the wastewater surveillance of COVID-19 in the community. SCi Total Environ 2020;728:138764.

15. Fongaro G, Stoco PH, Sobral Marques Souza D, Grisard EC, Magri ME, Rogovski P, et al. SARS-CoV-2 in human sewage in Santa Catalina, Brazil, November 2019. medRxiv 2020.

16. Prado $T$, Fumian $T M$, Mannarino $C F$, Maranhão $A G$, Siqueira MM, Miagostovich MP. Preliminary results of SARS-CoV-2 detection in sewerage system in Niterói municipality, Rio de Janeiro, Brazil. Mem Inst Oswaldo Cruz 2020;115:e200196.

17. Mlejnkova H, Sovova K, Vasickova P, Ocenaskova V, Jasikova L, Juranova E. Preliminary study of Sars-Cov-2 occurrence in wastewater in the Czech Republic. Int I Environ Res Public Health 2020;17:5508.

18. Westhaus S, Weber FA, Schiwy S, Linnemann V, Brinkmann $M$, Widera $M$, et al. Detection of SARS-CoV-2 in raw and treated wastewater in Germany - Suitability for COVID-19 surveillance and potential transmission risks. Sci Total Environ 2021;751:141750

19. Trottier J, Darques R, Ait Mouheb N, Partiot E, Bakhache W, Deffieu MS, et al. Post-lockdown detection of SARS-CoV-2 RNA in the wastewater of Montpellier, France. One Health 2020;10:100157.

20. Wurtzer S, Marechal V, Mouchel JM, Maday Y, Teyssou R, Richard E, et al. Evaluation of lockdown impact on SARSCoV-2 dynamics through viral genome quantification in Paris wastewaters. medRxiv 2020.

21. Kumar M, Patel AK, Shah AV, Raval J, Rajpara N, Joshi M, et al. First proof of the capability of wastewater surveillance for COVID-19 in India through detection of genetic material of SARS-CoV-2. Sci Total Environ 2020;746:141326.

22. La Rosa G, laconelli M, Mancini P, Bonanno Ferraro G, Veneri $C$, Bonadonna $L$, et al. First detection of SARSCoV-2 in untreated wastewaters in Italy. Sci Total Environ 2020;736:139652.

23. La Rosa G, Bonadonna L, Lucentini L, Kenmoe S, Suffredini E. Coronavirus in water environments: Occurrence, persistence and concentration methods - A scoping review. Water Res 2020;179:115899. 
24. Rimoldi SG, Stefani F, Gigantiello A, Polesello S, Comandatore $F$, Mileto $D$, et al. Presence and vitality of SARS-CoV-2 virus in wastewaters and rivers. medRxiv 2020.

25. Haramoto E, Malla B, Thakali O, Kitajima M. First environmental surveillance for the presence of SARS-CoV-2 RNA in wastewater and river water in Japan. medRxiv 2020.

26. Randazzo W, Cuevas-Ferrando E, Sanjuán R, Domingo-Calap $P$, Sánchez G. Metropolitan wastewater analysis for COVID-19 epidemiological surveillance. Int I Hyg Environ Health 2020;230:113621.

27. Medema G, Heijnen L, Elsinga G, Italiaander R, Brouwer A. Presence of SARS-Coronavirus-2 RNA in sewage and correlation with reported COVID-19 prevalence in the early stage of the epidemic in the Netherlands. Environ Sci Technol Lett 2020:acs.estlett.0c00357.

28. Alpaslan Kocamemi B, Kurt H, Hacıoglu S, Yaralı C, Saatci AM, Pakdemirli B. First data-set on SARS-CoV-2 detection for Istanbul Wastewaters in Turkey. medRxiv 20089417.

29. Wu F, Zhang J, Xiao A, Gu X, Lee WL, Armas F, et al. SARSCoV-2 titers in wastewater are higher than expected from clinically confirmed cases. mSystems 2020;5(4):e0061420.

30. Sherchan SP, Shahin S, Ward LM, Tandukar S, Aw TG, Sch mitz $B$, et al. First detection of SARS-CoV-2 RNA in wastewater in North America: A study in Louisiana, USA. SCi Total Environ 2020;743:140621.

31. World Health Organization (WHO). Guidelines for environmental surveillance of poliovirus circulation. Available from: https://apps.who.int/iris/bitstream/handle/10665/67854/WHO_V-B_03.03_eng.pdf?sequence $=1$ (Accessed date: 10 November 2020).

32. Larsen DA, Wigginton KR. Tracking COVID-19 with wastewater. Nat Biotechnol 2020;38(10):1151-3.

33. Asghar H, Diop OM, Weldegebriel G, Malik F, Shetty S, EI Bassioni L, et al. Environmental surveillance for polioviruses in the Global Polio Eradication Initiative. I Infect Dis 2014;210 (Suppl 1):S294-303.
34. WHO. Water, sanitation, hygiene, and waste management for SARS-CoV-2, the virus that causes COVID-19. Available from: https://www.who.int/publications/i/item/ WHO-2019-nCoV-IPC-WASH-2020.4 (Accessed date: 29 July 2020).

35. Ahmed W, Bivins A, Bertsch PM, Bibby K, Choi PM, Farkas K, et al. Surveillance of SARS-CoV-2 RNA in wastewater: Methods optimisation and quality control are crucial for generating reliable public health information. Curr Opin Environ Sci Health 2020.

36. Michael-Kordatou I, Karaolia P, Fatta-Kassinos D. Sewage analysis as a tool for the COVID-19 pandemic response and management: the urgent need for optimised protocols for SARS-CoV-2 detection and quantification. I Environ Chem Eng 2020;8:104306.

37. Carducci A, Federigi I, Liu D, Thompson JR, Verani M. Making Waves: Coronavirus detection, presence and persistence in the water environment: State of the art and knowledge needs for public health. Water Res 2020;1 79:115907.

38. WHO. Status of environmental surveillance for SARS-CoV-2 virus. Available from: https://www.who.int/news-room/ commentaries/detail/status-of-environmental-surveillance-for-sars-cov-2-virus (Accessed date: 10 December 2020)

\section{Address for Correspondence/Yazıșma Adresi}

\section{Dr. Sabiha AYDOĞDU}

Department of Nutrition and Dietetics,

Hitit University Faculty of Health Sciences

Corum-Turkey

E-posta: sabihaaydogdu@hitit.edu.tr 